Ismayil M. Ismayilov

National Academy of Aviation, Baku, Azerbaijan

DOI: $10.25045 /$ jpit.v09.i2.02

ismayil.maa@gmail.com

\title{
EXPERT SYSTEM OF INTELLIGENT PILOT SUPPORT IN ON-BOARD COMPLEXES AND ITS SOFTWARE
}

The basic structure of the expert-advisory system of the crew's intellectual support for the diagnosis and prediction of aircraft subsystems and its software is proposed. The system uses a user interface using artificial intelligence when searching for causes of malfunctions on an airplane. If there is any difficulty in controlling the aircraft with the help of the pilot-navigation complex, the pilot addresses the ES for help, answering system questions via the operator interface. Using the completed knowledge base, the system will generate and provide the user with recommendations with the localization of malfunction.

Keywords: aircraft control systems, intelligent control systems, artificial intelligence systems, expert systems.

\section{Introduction}

One of the key trends of the future progress of aircrafts is the development of the basics for building the flight control and decision support systems. These systems for operative interaction with the object control (including aircraft and its subsystems) use the knowledge and experience of experts targeted at the analysis of constantly changing model of external and internal systems. In abovementioned systems, also called intelligent systems, knowledge about unknown features of object control and the environment is formulated in the process of training and adaptation, while the obtained information is used in the process of automated decision-making raising the quality of control.

The process is performed by the aircraft's crew, the main task of which is directly related to the solution of pilot-navigational tasks. The detailed information about the development of pilotnavigational complexes (PNK) is provided in [2], whereas the analysis of quantitative, measuring tools, and the tools for information display in PNK is given in [3]. Furthermore, regardless of the aircraft type, it is control is performed by the crew, which leads to the faults related to human behavior. During the flight, the aircraft crew interacts with the information-control field of the cabin by deflecting the control knobs of the aircraft, entering data into the subsystems of the PNC, and also receiving information from multifunction indicators, keypad indicators, etc. [1]. At the same time, the peculiarities associated with psychophysiology of a pilot affect this interaction. Many available PSCs notify the crew about reaching the extreme flight regimes, failure of navigational equipment and overall condition of $\mathrm{PNC}$, or provide recommendations established in the flight manual. In case of certain combinations of external factors and failures of navigation equipment that arise in specific flight situations, the crew undergoes strong psycho-emotional overloads and has limited time to make a decision. This leads to the emergence of critical errors in the aircraft control (human factor) [4].

Since the crew's ability to parry specific situations arisen on board is limited, it is necessary to introduce an intelligent component into PNC, i.e., "virtual expert", which accumulates the experience of real experts in the field of navigation and piloting aircraft in specific situations. This circumstance necessitates the development of on-board systems equipped with board expert systems (ES). These systems reduce the psychophysiological load on the aircraft's crew and enable to conclude that the further development of PNC is closely related to the introduction of intelligent support for crew, situational awareness systems and further intellectualization of aircraft control $[5,6]$. 


\section{Problem statement}

Proceeding from abovementioned reasoning, the problem of development and use of a specialized human-machine expert system for the analysis of the causes of faults both in material part and control of the aircraft arises. The main goal of developing an expert system is to increase the efficiency of search through a mobile user interface with the use of artificial intelligence when searching for the causes of malfunctions on an airplane. In case of any complications in aircraft control, a pilot calls on the ES by means of pilot-navigation complex for help answering the system's questions via an operator interface. With the use of completed knowledge base, the system generates and issues recommendations on the localization of the fault for the user. Meanwhile, in subsystems of the aircraft, it explains the course of its reasoning via the explanatory module (even with incomplete information) indicating the level of expert's confidence [7].

\section{Problem solution}

The expert-advisory system and its software for diagnostics and prediction of aircraft subsystems are proposed. A generalized scheme of the basic structure of ES of intellectual crew support and its interaction in the composition of PNC for the aircraft is shown in Fig.1.

As it is seen from the chart, the data sensed from the sensors and board equipment comprising the flight-navigation complex are received and processed first in the corresponding block, and then sent to the working memory of ES as the evidences. Further, using logical inference machine and knowledge base, the system generates an assessment of the situation and seeds it to the reporting unit to the crew. Then the messages are sent via the communication channel to the control information field of the cabin for direct display to the aircraft's crew.

The knowledge base of the expert system $[8,9]$ records a list of possible problem situations. A specific response to each of them and a recommendation or an event to be directly performed is compared. Having received a response from a user about a real problem situation, the system exceptionally determines the correspondence of this information with one or more "templates" stored in the knowledge base. The information is obtained as a result of asking questions in a sequential order. Since, as a rule, the content of subsequent questions depends on the answers to the previous questions. Each piece of new information sent in the form of answer to a specific question reduces the uncertainty about the problem situation. Obviously, uncertainty reduces only if the expert system has relevant knowledge. A correctly constructed system has to be able to accurately identify the problem situation with the minimum number of questions. 


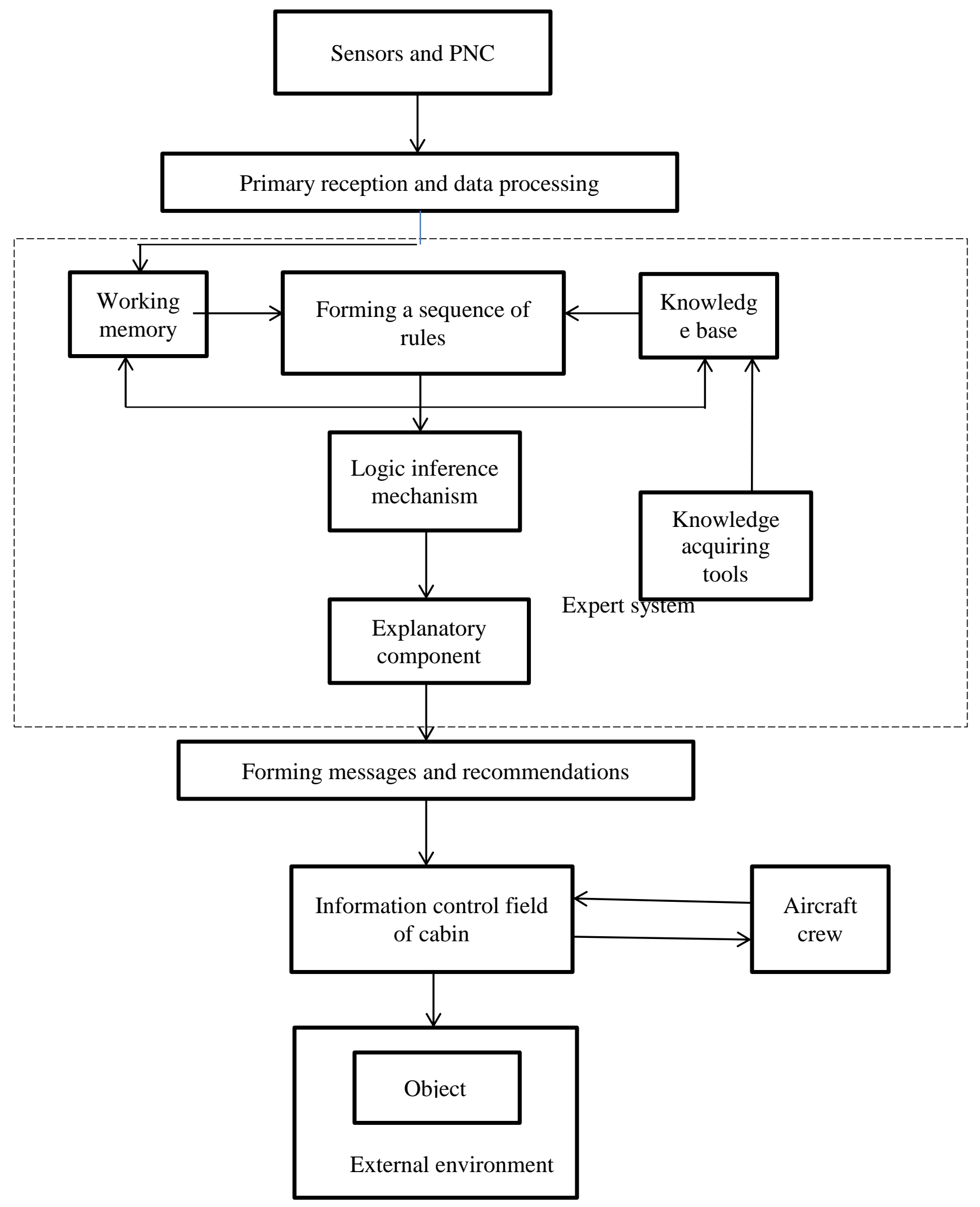

Fig.1. Basic structure of ES of intellectual aircraft crew support 
A flow chart of the algorithm for expert system functioning is shown in Fig.2

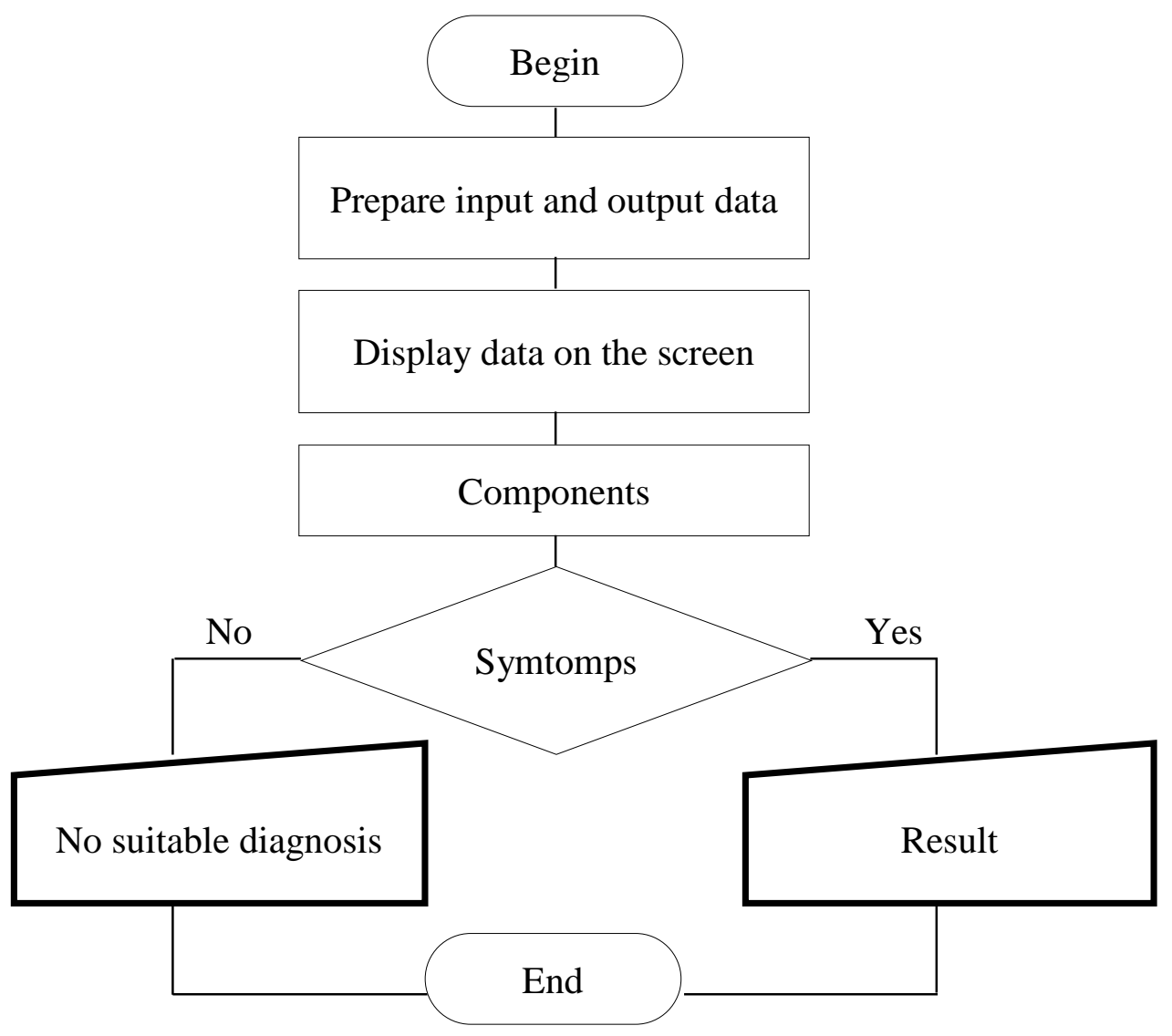

Fig.2 A flow chart of the algorithm for ES functioning

Before visualizing the program, its base is created first. The base is mostly prepared on Microsoft Access. This database includes three interconnected tables. The first table contains a list of problems that arise in board equipment during an aircraft flight. Typical problems that arise in front of a user (pilot) are displayed in Table 1.

This table uses an expression "type" to indicate which subsystem the fault is related to. The expression is of particular importance in safe control of a modern aircraft. The table is linked to other tables via the keywords "FMS", "EFIS", "EICAS". Requests are directed on the "type" field. adoquery1.SQL.Text:='select $*$ fromproblemlerwheretip $=:$ tip';

ADOQueryl.parameters.parambyname('tip').value:='FMC';

adoquery1.ExecSQL (table 1)

adoquery1.Open; 


\section{Table 1}

Typical problems encountered by a user (pilot)

\begin{tabular}{|c|c|c|c|}
\hline \multicolumn{4}{|c|}{ Проблемы } \\
\hline Код . & Проблема & $\cdot$ & Tнп \\
\hline & Канал управления & & FMC \\
\hline & Канал наблюдения & & FMC \\
\hline & Информационный канал & & FMC \\
\hline & Неполапка концентратора & & FMC \\
\hline & Неполапка MCDU & & FMC \\
\hline & Неполапка в шине ARDNC-429 & & FMC \\
\hline & Неполапка PFD и ND & & FMC \\
\hline & Двигатель самолёта & & FMC \\
\hline 9 & Неполапка в дисплее препупреждения двигателя & & EFIS \\
\hline & Неполапка в дисплее PFD & & EFIS \\
\hline & Неполапка в дисплее ND & & EFIS \\
\hline 12 & Неполапка в дисплее ECAM & & EFIS \\
\hline 13 & Неполапка в дисплее FWC & & EFIS \\
\hline 14 & Неправильное отображение параметров двигателя & & EICAS \\
\hline 15 & Не чувствуется регулярность в работе двигателя & & EICAS \\
\hline 16 & Неполность поясняются ошибки системы EICAS во время & & EICAS \\
\hline 17 & Запержка пожарной сигнализации двигателя & & EICAS \\
\hline 18 & Не работает сигналияация предупреждения силы тяги & & EICAS \\
\hline
\end{tabular}

The second table contains "symptoms". In this table, each problem corresponds to several symptoms. The key field connecting tables with other ones is the "problem" field. adoquery1.SQL.Text: ='select simptomı from simptomı whereproblem=:prob'; adoquery1.Parameters.ParamByName('prob').Value:=listboxl.items[listboxl.itemindex] ; adoquery1.execsql; adoqueryl.Open;

Table 2

Table of "symptoms"

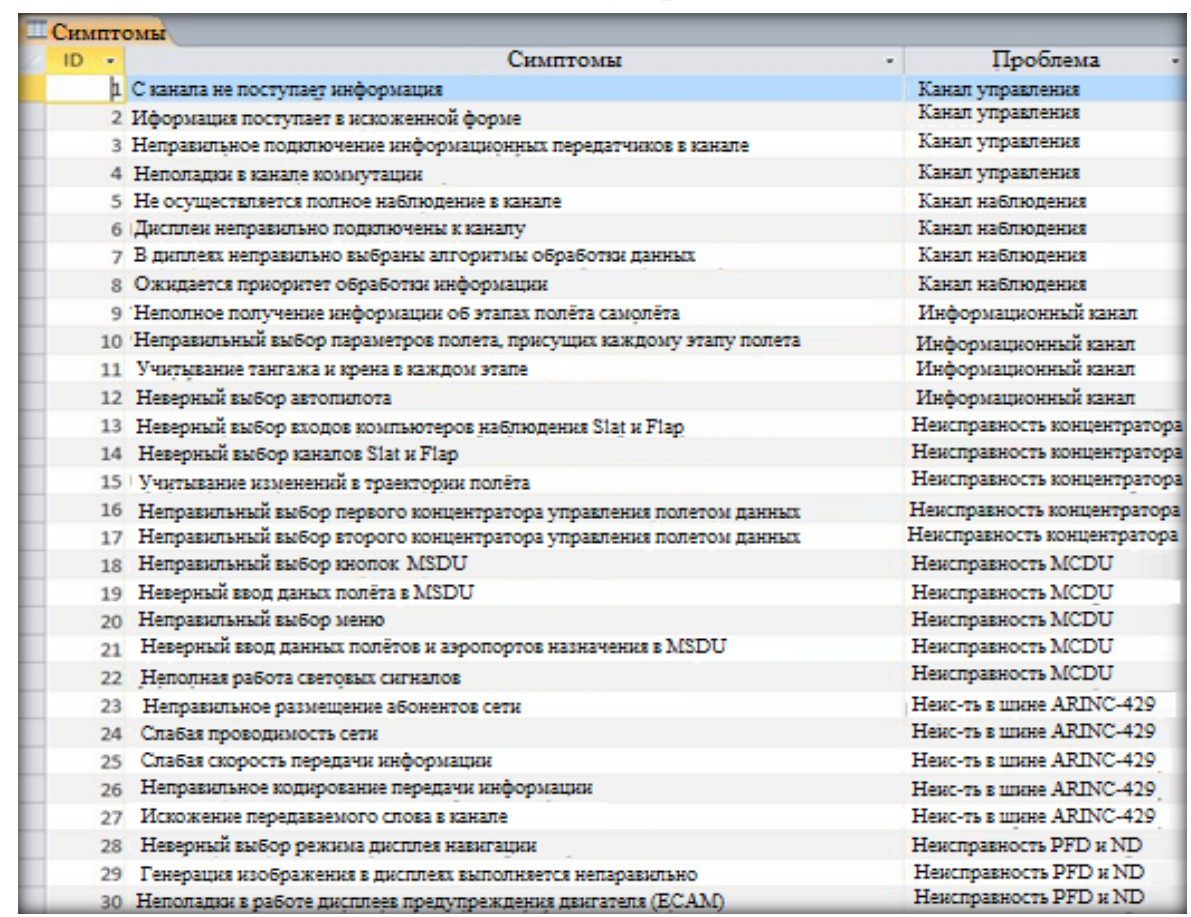


The third table contains "diagnoses", where the keyword is the "type" field. adoquery1.SQL.Text:='select * from diaqnozı where say=:analiz and tip=:tip'; adoquery1.Parameters.ParamByName('tip').Value:=listbox1.items[listboxl.itemindex]; adoquery1.Parameters.ParamByName('analiz').Value:=analiz; adoqueryl.execsql;

Table of "diagnoses"

\begin{tabular}{|c|c|c|c|c|}
\hline \multicolumn{5}{|c|}{ Zmarnoses } \\
\hline ID & - & & - Cभễ : & Tran \\
\hline & 1 & 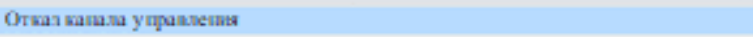 & 3 & Kanan упрам⿻ения \\
\hline & & 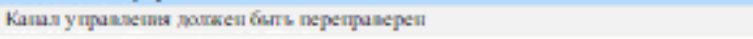 & 7 & Капал уиравлепия \\
\hline & 3 & 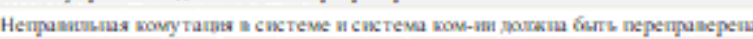 & 3 & 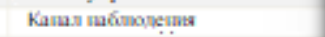 \\
\hline & 4. & 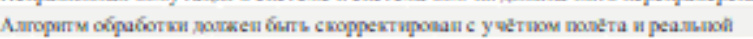 & 7 & 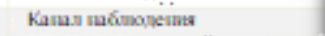 \\
\hline & s) & 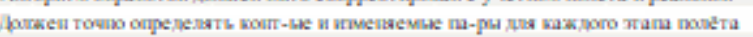 & 3 & 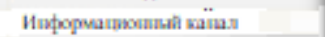 \\
\hline & 6 & 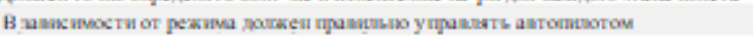 & 7 & 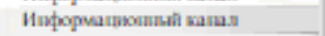 \\
\hline & 7 & 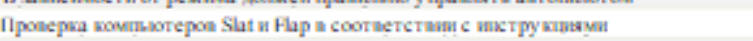 & 3 & Hencupannocts wonnempatopa \\
\hline & 8 & 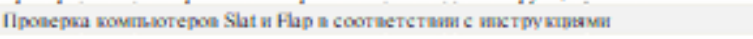 & 12 & Hencipanuocts wouneurрuгора. \\
\hline & 9 & 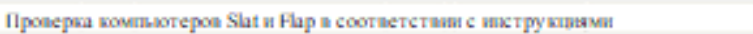 & 15 & Hencripanocts wonnempatopa \\
\hline & 10 . & 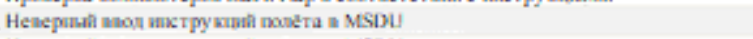 & 3 & Henknрапиоeть MCDDU \\
\hline & & 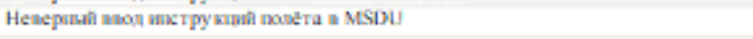 & 7 & Hencripanocts MCDPU \\
\hline & & 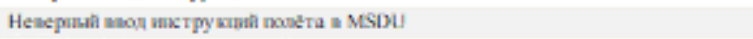 & 10 & Hencripanosets MCDUL \\
\hline & 13 & 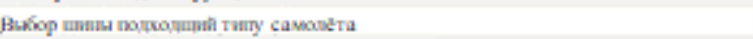 & 5 & 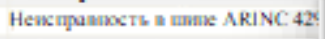 \\
\hline & 14 & Heпрамимимй мккор тиц сети & 10 & Hencripanocts a mane $\mathrm{ARINC} .42$ \\
\hline & & 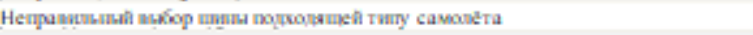 & 7 & Hencrupanosets a mane ARINC: 42 \\
\hline & & 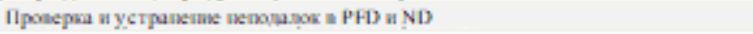 & 3 & Hencпраниость $\mathrm{PFD}$ и $\mathrm{ND}$ \\
\hline & & 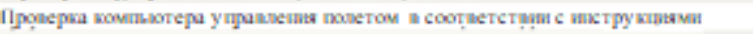 & 7 & Heиспраниость $\mathrm{P} F \mathrm{D}$ и ND \\
\hline & & 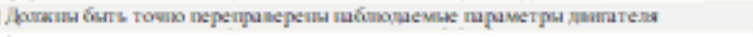 & 3 & Anaratem cavoostra \\
\hline & & He pá́otaet сиктемa FICAS & 7 & 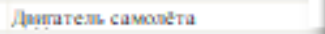 \\
\hline & & 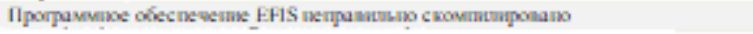 & 1 & 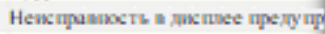 \\
\hline & & 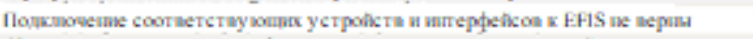 & 5 & 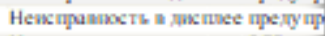 \\
\hline & & 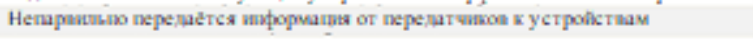 & 3 & Hencnpanostb a nacmsee PFD \\
\hline & & 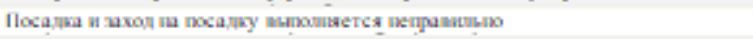 & 7 & Hencripanocts a macruse P'PD \\
\hline & & 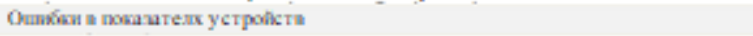 & 3 & Heucrpannosth a masrosee ND \\
\hline & & 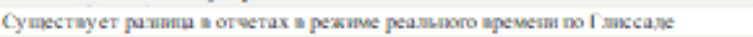 & 7 & Hencupanosts a mususee ND \\
\hline & & 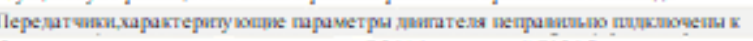 & 1 & Hencripanosts a macrive ECAM \\
\hline & & 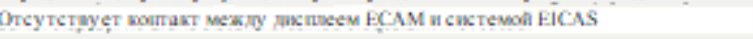 & s & 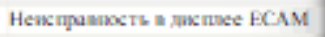 \\
\hline & & 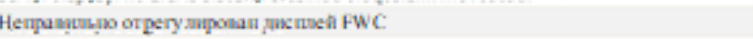 & 3 & Hencnpanocts a sacruse FWC \\
\hline & & 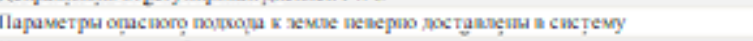 & 7 & Hencripunocts a macruse FWC \\
\hline & 304 & 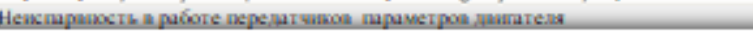 & & Muharnkin Qarametrilarinin d0z\&un \\
\hline
\end{tabular}

The primary program window opened during compilation is shown in Fig. 3.

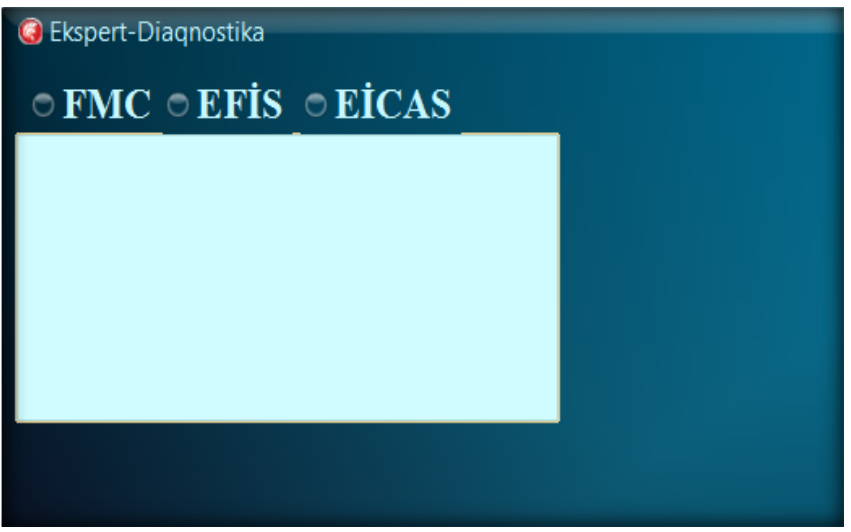

Fig.3. Primary program window

As it is seen from the opened window, the program consists of three parts, each part of which characterizes the problems arising in the individual aircraft subsystems.

A brief description of the main subsystems of the aircraft is given below: 
1. FMC - Flight Management Computer - designed to assist pilots in the implementation of flight modes. The main function of FMC is to precisely define location and direction of the aircraft on a given route.

2. EFIS - Electronic Flight Instrument System -consists of a Primary flight display (PFD) and a Navigation Display (ND). These displays are designed in pairs for both the Captain and Firstofficer.

3. EICAS - Engine Indicating and Crew Alerting System - principally designed for controlling engines and their parameters. Two system computers receive analog and digital data from various aircraft systems and sensors, analyze them and generate signals for indication. One of the computers controls both displays, and the other remains in reserve.

The opened window displays corresponding problems when clicked on its any corresponding section (FMC, EICAS, EFIS) (Fig. 4, Fig. 5, Fig. 6).

\begin{tabular}{|c|c|}
\hline 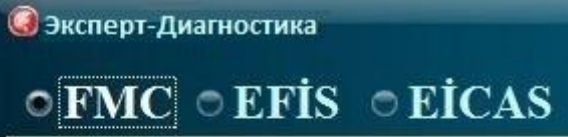 & $\begin{array}{l}\text { (9)сперт-диагностика } \\
\text { FMC OFIS } \odot \text { EICAS }\end{array}$ \\
\hline $\begin{array}{l}\text { Канал управления } \\
\text { Канал котроля } \\
\text { Информационный канал } \\
\text { Неисправность концетратора } \\
\text { Неисправность MCDU } \\
\text { Неисправность ARINC } 429 \\
\text { Неисправности PFD и ND } \\
\text { Двигатель самолёта }\end{array}$ & $\begin{array}{l}\text { Неисправность дисплея состояния двигателей } \\
\text { Неисправность дисплея PFD } \\
\text { Неисправность дисплея ND } \\
\text { Неисправность дисплея ECAM } \\
\text { Неисправность дисплея FWC }\end{array}$ \\
\hline
\end{tabular}

Fig.4. Malfunctions in subsystem FMC Fig.5. Malfunctions in subsystem EFIS

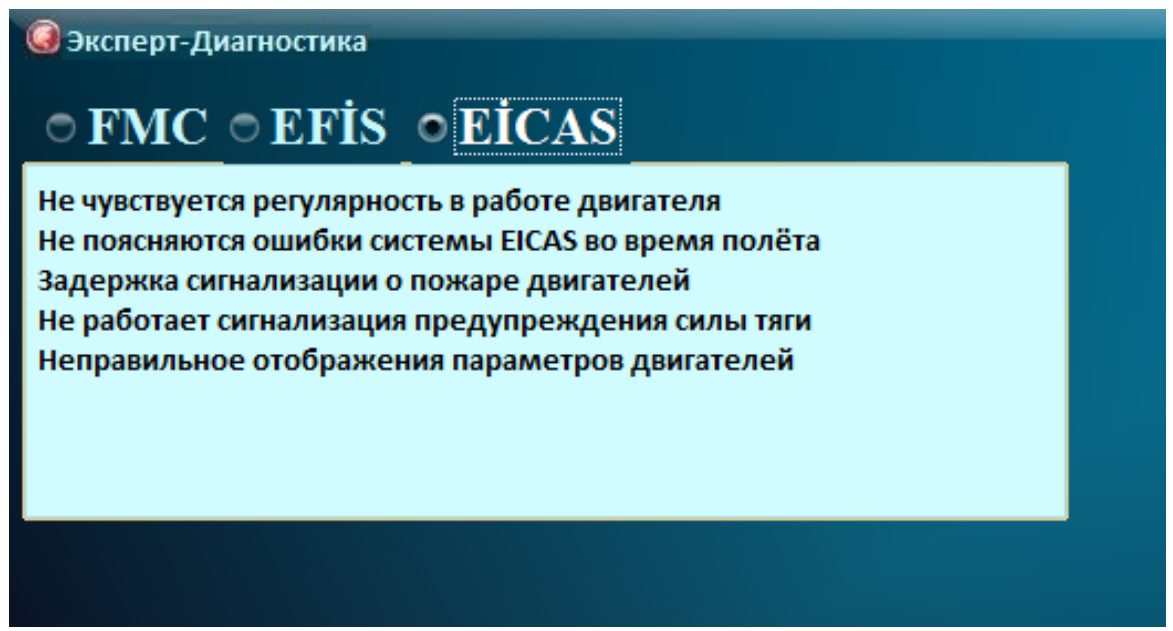

Fig.6. Malfunctions in subsystem EICAS

As it is seen, screen displays problems specific to each field. Here, each problem corresponds to several symptoms. Clicking on these symbols separately for each problem, the followings will display (Fig. 7). 


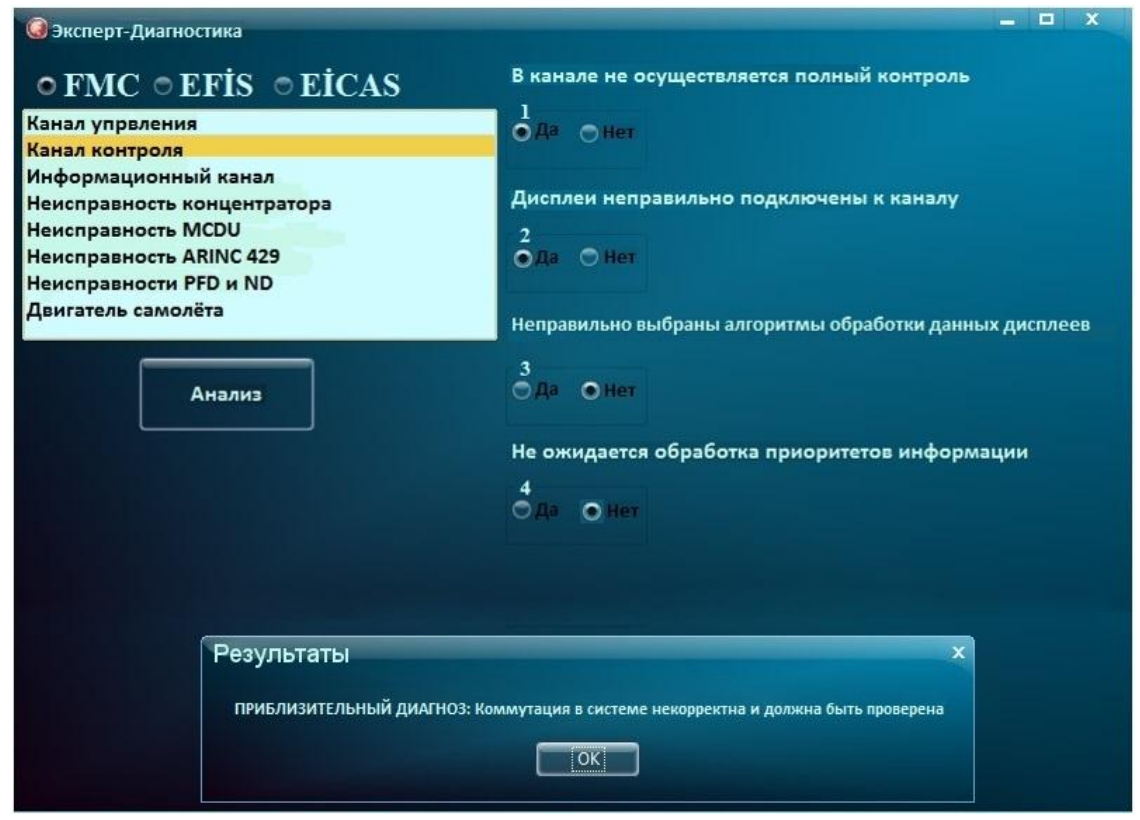

Fig.7. Determination of the diagnosis on corresponding symptoms in section "Control channel" of "FMC"

The figure illustrates a problem in section "Control Channel" of system "FMC". Here, several estimated symptoms corresponding to the occurrence of the problem are identified (highlighted). The program will give different diagnoses depending on the symptom selected. Once the diagnosis corresponding to the problem is selected, "Analysis" button is clicked. The diagnosis corresponding to the $1^{\text {st }}$ and $2^{\text {nd }}$ symptoms is provided below (Fig. 8).

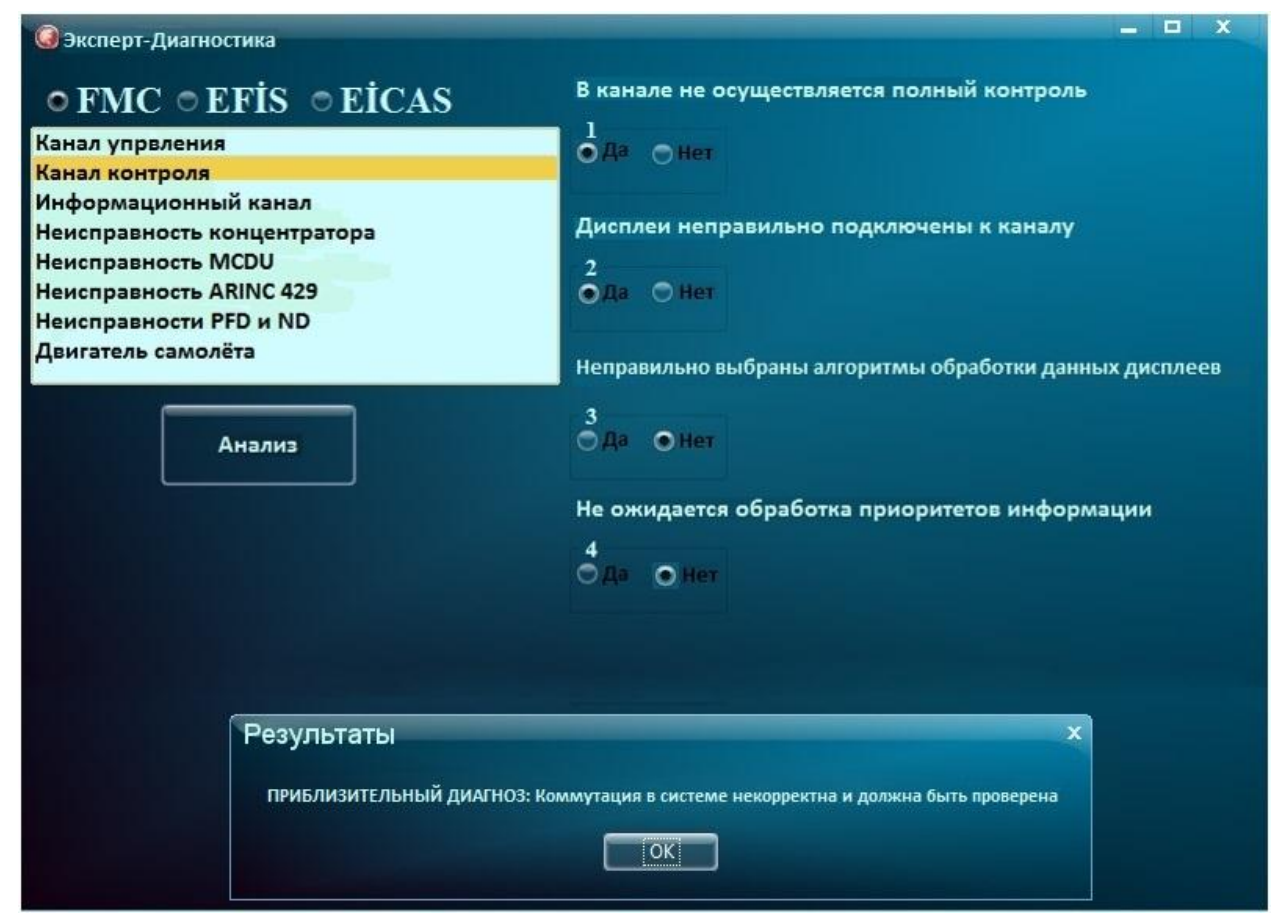

Fig.8. Diagnosis corresponding to the $1^{\text {st }}$ and $2^{\text {nd }}$ symptoms

The diagnosis corresponding to the $3^{\text {rd }}$ and $4^{\text {th }}$ symptoms is as follows (Fig. 9). 


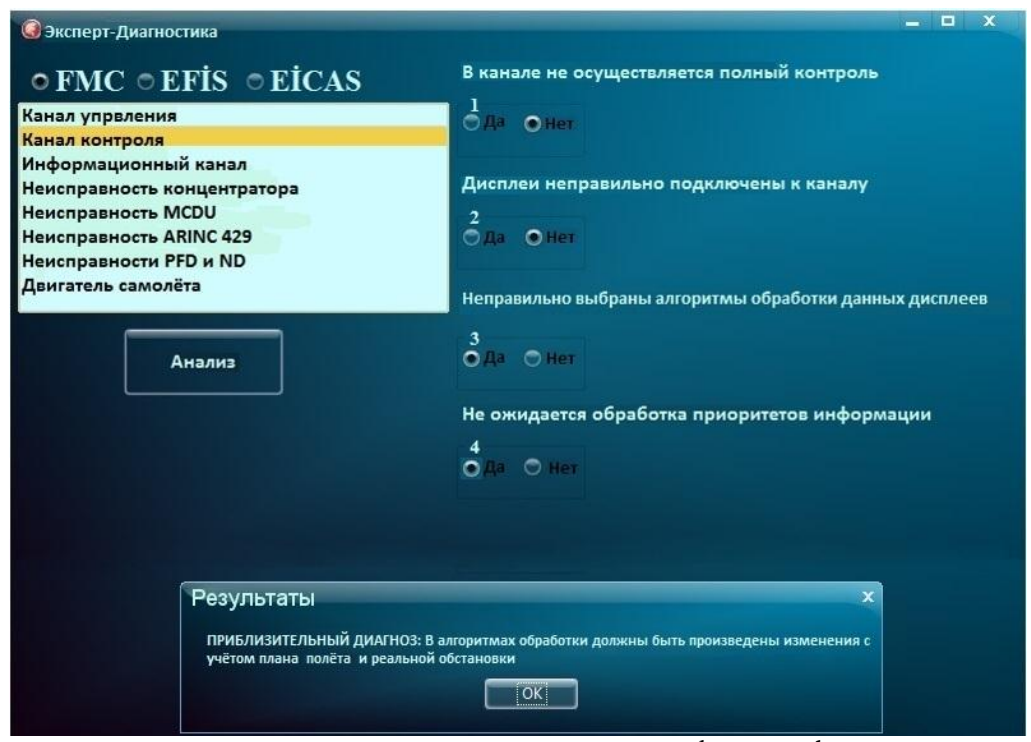

Fig.9. Diagnosis corresponding to the $3^{\text {rd }}$ and $4^{\text {th }}$ symptoms

Thus, the development of the expert advisory system and its software for diagnosing and forecasting important aircraft subsystems such as FMC, EFIS and EICAS provides information support to the pilot and assists to make the right decision.

\section{Conclusion}

Based on the analysis that the further development of the PNC was closely related to the introduction of intelligent crew support, situational awareness systems and further intellectualization of the aircraft control, a basic structure of the expert and advisory system of the intellectual crew support for the diagnosis and prediction of aircraft subsystems and its software were proposed. To visualize the program, a database was created, which consisted of three interrelated tables: typical problems that arise in front of user (pilot) during the flight; several symptoms corresponding to each problem, and a table of diagnoses. The order of work with the program and examples of the user's dialogue with the expert system were given.

\section{References}

1. Zemlyanniy E.S. Pilot-navigational complex with intellectual support of aircraft's crew. Thesis for the degree of PhD of Technical Sciences. Moscow State Technical University named after N.E. Bauman. Moscow - 2016, pp.45-48.

2. Avgustov I. et al. Navigation of aircraft in the near-Earth space, edited by G.I. Djandzhgava, M .: "Nauchtekhlitizdat" LLC, 2015, 592 p.

3. Perfiliev O.V., Rizhakov S.G. Expert system for analyzing the causes of malfunctions for aviation equipment // Aviation and Rocket and Space Technology, News of Samara Scientific Center, Russian Academy of Sciences, 2016, vol.18, No4 (3), pp.564-570.

4. Lapa V.V., Ponomarenko V.A., Chuntul A.V. Psychophysiology of flight safety. M.: IPO "Association of journalists writing on law enforcement", 2013, $396 \mathrm{p}$.

5. Babichenko A.V., Zemlyaniy E.S. To justify the requirements for on-board expert systems of intelligent crew support, // Aerospace instrumentation, 2014, No12, pp.26-37.

6. Ribina G.V. Intelligent systems: from A to Z. A series of monographs in three books. Book 1. Knowledge-based systems. Integrated expert systems. M .: "Nauchtekhlitizdat" LLC, 2014, 223 p.

7. Perfiliev O.V. Expert system of intelligent support for aviation specialists in the maintenance of aircraft systems and equipment // News of Samara Scientific Center, Russian Academy of Sciences, 2014, vol.16, No. 1 (5), pp.1545-1549.

8. Gavrilova T.A., Khoroshevsky V.F. Knowledge bases of intelligent systems. St. Petersburg: Peter, 2000, $384 \mathrm{p}$.

9. Expert system - with own hands. www.softkey.info/reviews/review464.php 